\title{
Structure and Diversity of Endoparasitic Infracommunities and the Trophic Level of Pseudoplatystoma corruscans and Schizodon borelli (Osteichthyes) of the High Paraná River
}

\author{
Marion Haruko Machado, Gilberto Cezar Pavanelli/ + , Ricardo Massato \\ Takemoto*
}

Curso de Pós-Graduação em Ecologia de Ambientes Aquáticos Continentais, Universidade Estadual de Maringá, DBI/NUPELIA, Av. Colombo 5790, 87020-900 Maringá, PR, Brasil *Curso de Pós-Graduação em Ecologia e Recursos Naturais, Universidade Federal de São Carlos, Caixa Postal 676, 13565-905 São Carlos, SP, Brasil

One hundred and ten specimens of Pseudoplatystoma corruscans (Pimelodidae) and 582 specimens of Schizodon borelli (Anostomidae) collected in the high Paraná River were analyzed. On necropsy $74 \%$ of $\mathrm{P}$. corruscans were found to be parasitized; proteocephalidean cestodes presented the greatest number. With regard to $\mathrm{S}$. borelli, the percentage of parasitism reached $19.42 \%$ and the nematode Cucullanus pinnai was the most abundant. The absence of correlation between the endoparasitic diversity and the standard length of the two host species indicates that each one presents homogeneity in alimentary behaviour during all its life time, permiting the uniform recruitment of the same species of endoparasites during all its ontogenetic development. Independence of diversity values in relation to sex of $\mathrm{P}$. corruscans and $\mathrm{S}$. borelli evidences that the ecological relationships are similar between males and females in these species. Both host's infrapopulations presented a typical overdispersed pattern of distribution with isolationist characteristics.

Key words: endohelminths - freshwater fish - Pseudoplatystoma corruscans - Schizodon borelli - high Paraná River - diversity - structure of infrapopulations - Brazil

The great diversity of habitats and organisms found in the floodplains produces a complex situation with regard to the study of their ecological interactions since periodic floods provoke changes of environment with modifications in the habitat, supply of food, alimentary behaviour of the species and the composition of the parasitofauna of fish.

Among the factors that influence the composition of endoparasitic fauna, the host's alimentary habit is the most important characteristic since it may include numerous animals which have the role of intermediate hosts (Dogiel 1970).

This research work intends to analyze some ecological interrelationships among species of endohelminths and the interrelationships of these species with the hosts. It proposes to compare the fauna diversity of endoparasites of two species of fish of distinct trophic categories: Pseudoplatystoma corruscans (Agassiz 1829) (Siluriformes: Pimelodidae), "pintado", a carnivorous fish widely distributed in South America (Fowler 1951)

Supported by CNPq - PADCT/CIAMB.

${ }^{+}$Corresponding author and research fellow CNPq. Fax: 55-44-226.1860

Received 10 October 1995

Accepted 22 February 1996 and Schizodon borelli (Boulenger 1900) (Characiformes: Anostomidae), "piava", an herbivorous fish extremely common in the floodplain of the Paraná River (UEM/NUPELIA, unpublished observations). In another work the authors analyzed the influence of host's sex and size (Machado et al. 1994) and the influence of type of environment and hydrologic level variation (Machado et al. 1995) on endoparasitic infrapopulations of $P$. corruscans and $S$. borelli of the high Paraná River.

\section{MATERIALS AND METHODS}

The area under analysis lies in the floodplain of the Paraná River, municipality of Porto Rico, Paraná, Brazil $\left(22^{\circ} 40^{\prime}-22^{\circ} 50^{\prime} \mathrm{S}\right.$ and $53^{\circ} 15^{\prime}-$ $53^{\circ} 40^{\prime} \mathrm{W}$ ) (Fig. 1). Due to a great diversity of habitats, sampling was undertaken in three types of environments with distinct characteristics: (a) lentic environment represented by the lakes Patos and Guaraná; (b) a semi-lotic environment represented by the River Baía and (c) a lotic environment represented by the principal course of the Paraná River, by the channel Cortado and the River Ivinheima (Fig. 1) (Thomaz 1991).

Monthly collections were undertaken from March 1992 to February 1993. Fishing equipment consisted of simple nets, gill nets and boulters which were set during $24 \mathrm{hr}$ with hauling at every $4 \mathrm{hr}$. After capture and identification of fish, total 


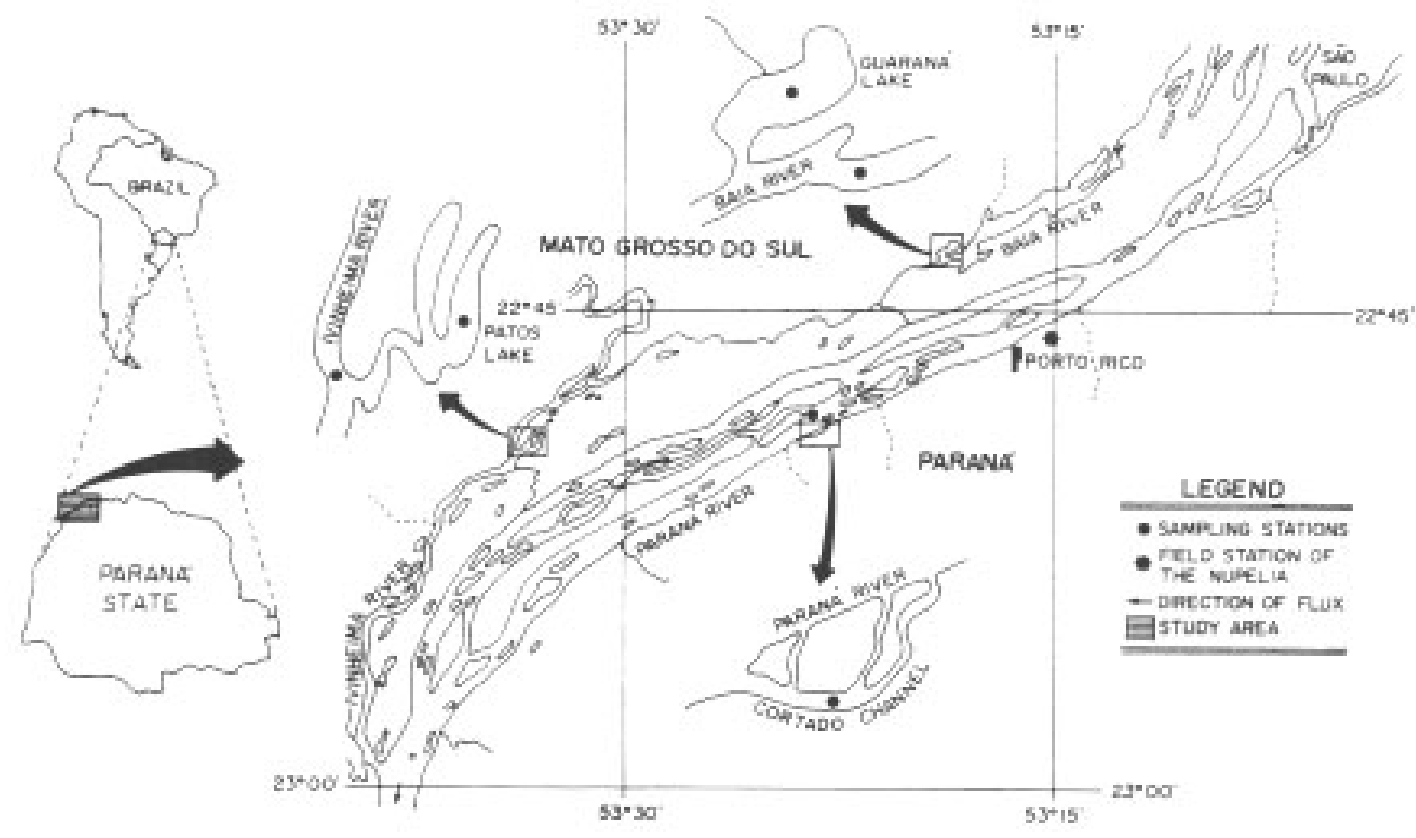

Fig. 1: sites of the collecting points: Patos Lake, Guaraná Lake, Baía River, Paraná River, Cortado Channel and Ivinheima River, in the high Paraná River, region of Porto Rico, Paraná, Brazil.

and standard length, weight and sex were determined. Fish were eviscerated and their visceral cavity examined. The organs examined by stereoscopic microscope on the site were: eyes, digestive tube and adjacent organs, kidneys, urinary bladder, swimming bladder and gonads. Endoparasites collected were cleaned in a $0.65 \%$ physiological solution and prepared according to Amato et al. (1991). Helminths were deposited in the Helminthological Collection of the Instituto Oswaldo Cruz (CHIOC) in Rio de Janeiro, Brazil (CHIOC n ${ }^{\circ} 33.270$ to $\left.\mathrm{n}^{\circ} 33.285\right)$.

The dispersion index (relation between variance and the mean number of parasites) was used to determine the pattern of infrapopulation distribution. The degree of superdispersion or parasite aggregation was obtained by the calculation of the inverse of parameter $\mathrm{k}$ negative binomial (Pielou 1976) and by Green's index (Ludwig \& Reynolds 1988). This test was applied only to those species of endoparasites which presented prevalence superior to $5 \%$. To determine concentration for dominance among species of endoparasites, Simpson's Index "C" was used and the concentration for dominance was assumed when $C \geq 0.25$ (Stone \& Pence 1978). Parasitic diversity was calculated by the Shannon index " $H$ " and the possible variation of parasitic diversity was also analyzed in relation to sex (Student's " $t$ " test) and to the hosts' standard length (Spearman rank correlation coefficient "rs"). The Pielou Evenness index (J') was also calculated for each infracommunity (Ludwig \& Reynolds 1988). Bush's Importance value "I", according to Thul et al. (1985), was used to classify the species of endohelminths according to their importance in the endoparasitic community. Species in the larval stage were not considered in this classification. Possible interspecific associations between pairs of co-occurring species were determined by the Chi-square analysis, using the Yates correction. The degree of association was determined by the indexes of Ochiai, Dice and Jaccard (Janson \& Vegelius 1981, Ludwig \& Reynolds 1988). Possible correlations between intensity of species which formed associations were analyzed by Spearman rank correlation coefficient "rs". For data analysis only those with a significant level of $\mathrm{P} \leq$ 0.05 were considered significant. Computer program for statistical tests and calculation of ecological indexes was Statistical Ecology (Ludwig \& Reynolds 1988). Terms related to parasitic ecology were those suggested by Margolis et al. (1982) and Holmes and Price (1986).

\section{RESULTS}

Pseudoplatystoma corruscans - Eighty-two (74.54\%) out of the 110 hosts examined were parasitized by one or more species of parasites, totalling 6,259 specimens with mean intensity of infection of 76.68. Endohelminths collected included five species of cestodes [Choanoscolex abscissus (Riggenbach, 1895), Spasskyelina spinulifera 
(Woodland, 1935), Nomimoscolex sudobim Woodland, 1934, Megathylacus travassosi Pavanelli \& Rego, 1992 and Harriscolex kaparari (Woodland, 1935)] and five species of nematodes [Cucullanus pseudoplatystomae Moravec, Kohn \& Fernandes, 1993, Eustrongylides sp. (larvae), Contracaecum sp. 1 (larvae), Contracaecum sp. 2 (larva) and Procamallanus (Spirocamallanus) sp.] (Table I).

Richness of endoparasites had a broad variety ranging from 1 to $7: 15$ hosts $(18.29 \%)$ presented monospecific infection; 16 hosts $(19.51 \%)$ were infected by 2 species; 33 (40.24\%) by 3 species; $11(13.41 \%)$ by 4 species; $3(3.66 \%)$ by 5 and 6 species and 1 (1.22\%) by 7 species (Fig. 2).

Cestodes were the parasites with the greatest prevalence and mean intensity of infection, occurring in 81 hosts $(73.34 \%)$ representing $98.95 \%$ (6,222 specimens) and mean intensity of infection of 77.78. C. abscissus was the most abundant species and with the great mean intensity of infection. S. spinulifera was the most frequent (Table I). Nematodes constituted $1.02 \%$ of all endoparasites collected, occurring in 18 hosts $(16.36 \%)$, with a mean intensity of infection of $3.37 \%$.

Endoparasitic fauna of $P$. corruscans was not so concentrated as to constitute dominance according to the Simpson index " $C$ " $(C=0.20)$. Endoparasitic diversity, according to Shannon index was $\mathrm{H}$ $=0.6140($ standard deviation $=0.3637)$ and Pielou's Evenness index (J') presented a mean of 0.6966 (standard deviation $=0.1961)$. Endoparasitic diversity showed neither any significant difference between male and female hosts $(t=1.33$; $0.10<\mathrm{P}<0.20)$ nor correlation to the size of the host $(\mathrm{rs}=0.149 ; 0.10<\mathrm{P}<0.20)$. Standard length

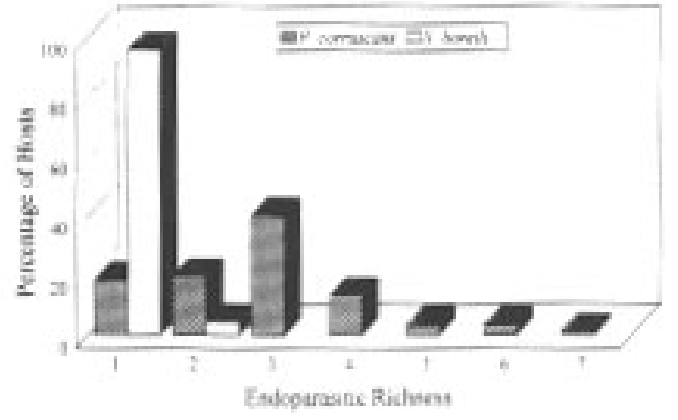

Fig. 2: endoparasitic richness in 110 specimens of Pseudoplatystoma corruscans and 582 specimens of Schizodon borelli collectes in the high Paraná River, region of Porto Rico, Paraná, Brazil, from March 1992 to February 1993.

of hosts varied between 17.6 and 87.5 (mean length 44.58).

According to the Importance values proposed by Bush, four species were classified as dominant, two as codominant and two as subordinate (Table II).

The endoparasitic community presented high values of dispersion index, of Green's Aggregation index and the inverse of parameter $\mathrm{k}$ negative binomial (Table III), thus presenting a typical overdispersed pattern of distribution of endoparasitic systems.

Among the 21 possible associations in the most frequent species of endohelminths, 13 pairs were positively correlated to parasitic intensity, 7 pairs of which were associated (Table IV). However, only 3 of these pairs had a high degree of association: $C$. abscissus - S. spinulifera $($ Ochiai $=0.815$; Dice $=0.815$ and Jaccard $=0.688$, C. abscissus -

\section{TABLE I}

Prevalence, intensity, relative density and site of infection of endoparasites in 110 specimens of Pseudoplatystoma corruscans collected in the high Paraná River, Porto Rico, Paraná, Brazil, from March 1992 to February 1993

\begin{tabular}{lccccc}
\hline Parasites $^{a}$ & ni & prev. (\%) & mi & a & rd \\
\hline CESTODA & & & & & \\
Choanoscolex abscissus (1) & 61 & 55.45 & 56.9 & $1-492$ & 31.55 \\
Spasskyelina spinulifera (1) & 65 & 59.09 & 18.6 & $1-134$ & 10.99 \\
Nomimoscolex sudobim (1) & 47 & 42.73 & 28.7 & $1-176$ & 12.26 \\
Megathylacus travassosi (1) & 23 & 20.91 & 7.1 & $1-88$ & 1.48 \\
Harriscolex kaparari (1) & 10 & 9.09 & 2.7 & $1-7$ & 0.24 \\
NEMATODA & & & & \\
Cucullanus pseudoplatystomae (1) & 9 & 8.18 & 1.2 & $1-3$ & 0.10 \\
Contracaecum sp. 1 (2) & 9 & 8.18 & 3.2 & $1-10$ & 0.26 \\
Contracaecum sp. 2 (2) & 1 & 0.91 & 1.0 & - & 0.01 \\
Eustrongylides sp. (2) & 2 & 1.82 & 10.0 & $1-19$ & 0.18 \\
Procamallanus (Spirocamallanus) sp. (1) & 1 & 0.91 & 3.0 & - & 0.03 \\
\hline
\end{tabular}

$a$ : numbers in parentheses indicate location in host: (1) small intestine and (2) mesentery.

ni: number of infected fish; prev: prevalence; mi: mean intensity of infection; a: amplitude of intensity variance; rd: relative density. 


\section{TABLE II}

Classification and values of Bush's Importance (I) of endoparasitic species in 110 specimens of

Pseudoplatystoma corruscans collected in the high

Paraná River, Porto Rico, Paraná, Brazil, from March 1992 to February 1993

Parasites I

\section{DOMINANT SPECIES}

Choanoscolex abscissus

59.178

Spasskyelina spinulifera

21.933

Nomimoscolex sudobim

Megathylacus travassosi

\section{CODOMINANT SPECIES}

Harriscolex kaparari

0.075

Cucullanus pseudoplatystomae

0.028

\section{SUBORDINATE SPECIES}

Procamallanus (Spirocamallanus) sp.
N. sudobim (Ochiai $=0.735$; Dice $=0.727$ and Jaccard $=0.571$ ) and S. spinulifera $-N$. sudobim (Ochiai $=0.706$; Dice $=0.696$ and Jaccard $=0.534)$.

S. borelli - One hundred and thirteen $(19.42 \%)$ out of 582 specimens examined were parasitized by one or more species of endohelminths, totalling 287 species and mean intensity of infection of 2.54. These included 5 species of digenetics [Ithyoclinostomum dimorphum (Diesing, 1850) (metacercaria), Diplostomum sp. (metacercariae), Clinostomum sp. (metacercariae), Saccocoelioides platensis Lunaschi, 1984, Paralecithobothrys brasiliensis Freitas, 1947], 4 species of nematodes [Procamallanus (Spirocamallanus) inopinatus Travassos, Artigas \& Pereira, 1928, Procamallanus (Spirocamallanus) iheringi Travassos, 1929, Piavussunema schubarti Kohn, Gomes \& Motta, 1968 and Cucullanus pinnai Travassos, Artigas \& Pereira, 1928] and 2 species of acanthocephalans [Octospiniferoides incognita Schmidt \& Hugghins,

\section{TABLE III}

Dispersion index (DI), Green's Aggregate index (GI) and values of inverse of parameter k negative binomial (1/k) of endoparasites in 110 specimens of Pseudoplatystoma corruscans collected in the high Paraná River, Porto Rico, Paraná, Brazil, from March 1992 to February 1993

\begin{tabular}{lrrc}
\hline Parasites & ID & $1 / \mathrm{k}$ & GI \\
\hline Choanoscolex abscissus & 198.514 & 6.610 & 0.057 \\
Spasskyelina spinulifera & 36.731 & 4.349 & 0.030 \\
Nomimoscolex sudobim & 77.828 & 8.319 & 0.057 \\
Megathylacus travassosi & 49.861 & 12.739 & 0.302 \\
Harriscolex kaparari & 4.200 & 17.452 & 0.123 \\
Cucullanus pseudoplatystomae & 1.459 & 36.364 & 0.046 \\
Contracaecum sp. 1 & 5.545 & 2.831 & 0.162 \\
\hline
\end{tabular}

\section{TABLE IV}

Correlation between abundances ("rs") and interspecific association (" $\chi 2$ ") of pairs of co-occurring endoparasites in 110 specimens of Pseudoplatystoma corruscans collected in the high Paraná River, Porto Rico, Paraná, Brazil, from March 1992 to February 1993

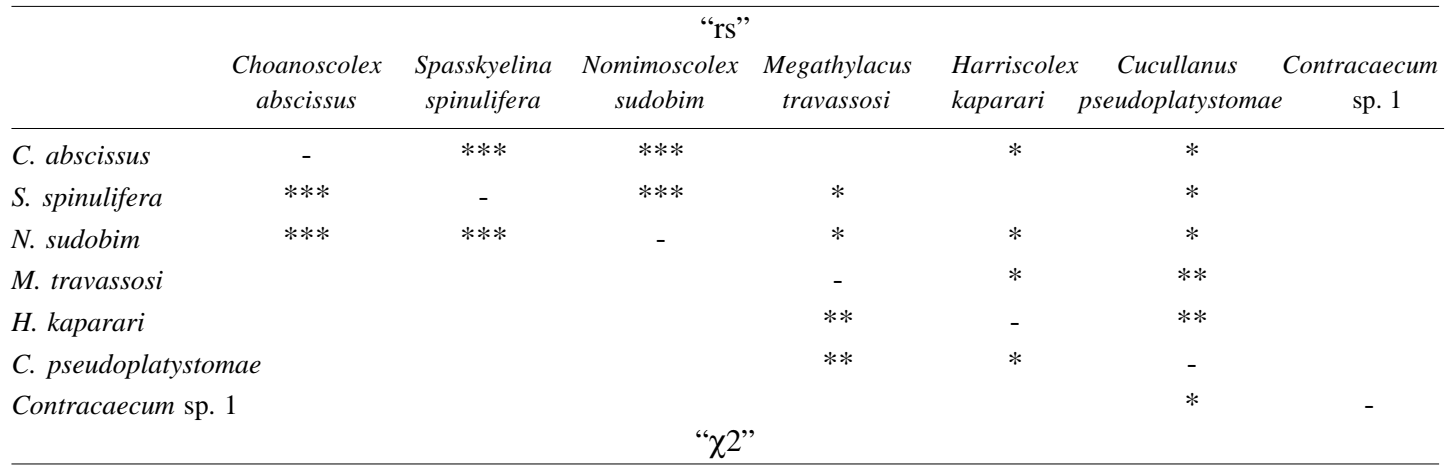

$* \mathrm{P}<0.05 ; * * \mathrm{P}<0.01 ; * * * \mathrm{P}<0.001$

"rs": Spearman rank correlation coefficient, $\chi 2=$ Chi-square 
1973 and Echinorhynchus sp.] (Table V). The richness of endoparasites consisted of a broad variety ranging from 1 to 2 . One hundred and eight hosts $(95.58 \%)$ presented monospecific infections and $5(4.42 \%)$ an infection by 2 species (Fig. 2).

Nematodes were the endoparasites with the greatest prevalence and mean intensity of infection, occurring in 64 hosts (11\%), representing $59.58 \%$ (171) of collected specimens and mean infection intensity of 1.44. C. pinnai was the most abundant and frequent species (Table V). Digenetic helminths constituted $32.06 \%$ (92 specimens) of total, occurring in 40 hosts $(6.87 \%)$ and mean intensity of infection of 2.3. Acanthocephalans occurred in 13 hosts $(2.23 \%)$ representing $8.36 \%$ of endoparasites and mean intensity of 1.84 .

Endoparasitic fauna of $S$. borelli had a concentration for dominance according to the Simpson index " $C$ " $(C=0.29)$. Mean endoparasitic diversity, according to Shannon index $\left(\mathrm{H}^{\prime}\right)$ was 0.0285 (standard deviation $=0.0695$ ) . Endoparasitic diversity showed neither any significant difference between male and female hosts $(t=0.40, \mathrm{P}>0.50)$ nor any correlation to the host's size $(\mathrm{rs}=0.024, \mathrm{P}$ $>0.50$ ). Standard length of hosts oscillated between 7.4 and 28.7 (mean 18.7).

According to the value of Importance proposed by Bush, two species were classified as dominant and seven as codominant (Table VI). Dispersion mean of endoparasites of $S$. borelli also presented an overdispersed pattern of distribution (Table VII). The most frequent species (Diplostomum sp. and C. pinnai) did not present any association between themselves.

\section{TABLE VI}

Classification and Bush's Importance Values (I) of endoparasite species in 582 specimens of Schizodon borelli collected in the high Paraná River, Porto Rico, Paraná, Brazil, from March 1992 to February 1993

Parasites I

DOMINANT SPECIES

Cucullanus pinnai

Octospiniferoides incognita

CODOMINANT SPECIES

Procamallanus (Spirocamallanus) inopinatus

0.871

Piavussunema schubarti

Echinorhynchus sp.

Saccocoelioides platensis

0.012

Paralecithobothrys brasiliensis

0.012

Procamallanus (Spirocamallanus) iheringi

0.012

\section{TABLE VII}

Dispersion index (DI), Green's Aggregate index (GI) and values of inverse of binomial negative $\mathrm{k}$ parameter $(1 / \mathrm{k})$ of endoparasites in 582 specimens of Schizodon borelli collected in the high Paraná River, Porto Rico, Paraná, Brazil, from March 1992 to February 1993

\begin{tabular}{lccc}
\hline Species of Endoparasites & DI & $1 / \mathrm{k}$ & GI \\
\hline Diplostomum sp. & 3.623 & 21.692 & 0.044 \\
Cucullanus pinnai & 4.170 & 16.611 & 0.022 \\
\hline
\end{tabular}

\section{TABLE V}

Prevalence, intensity, relative density and infection site of endoparasites in 582 specimens of Schizodon borelli collected in the high Paraná River, Porto Rico, Paraná, Brazil, from March 1992 to February 1993

\begin{tabular}{|c|c|c|c|c|c|}
\hline Species of Endoparasites ${ }^{a}$ & ni & prev. $(\%)$ & $\mathrm{mi}$ & a & rd \\
\hline \multicolumn{6}{|l|}{ DIGENEA } \\
\hline Ithyoclinostomum dimorphum (1) & 1 & 0.17 & 1.0 & - & 0.002 \\
\hline Diplostomum sp. (2) & 31 & 5.33 & 2.0 & $1-10$ & 0.106 \\
\hline Clinostomum sp. (3) & 3 & 0.52 & 5.7 & $1-9$ & 0.029 \\
\hline Saccocoelioides platensis (4) & 1 & 0.17 & 1.0 & - & 0.002 \\
\hline Paralecithobothrys brasiliensis (4) & 1 & 0.17 & 1.0 & - & 0.002 \\
\hline \multicolumn{6}{|l|}{ NEMATODA } \\
\hline Procamallanus (Spirocamallanus) inopinatus (4) & 8 & 1.37 & 1.1 & $1-2$ & 0.015 \\
\hline Procamallanus (Spirocamallanus) iheringi (4) & 1 & 0.17 & 1.0 & - & 0.002 \\
\hline Piavussunema schubarti (4) & 1 & 0.17 & 15.0 & - & 0.026 \\
\hline Cucullanus pinnai (4) & 54 & 9.28 & 2.7 & $1-10$ & 0.250 \\
\hline \multicolumn{6}{|l|}{ ACANTHOCEPHALA } \\
\hline Octospiniferoides incognita (4) & 12 & 2.06 & 1.7 & $1-9$ & 0.035 \\
\hline Echinorhynchus sp. (4) & 1 & 0.17 & 4.0 & - & 0.007 \\
\hline
\end{tabular}

$a$ : numbers in parentheses indicate location in host: (1) external wall of stomach, (2) eye (aqueous humor), (3) branquial arches and (4) small intestine.

ni: number of infected fish; prev.: prevalence; mi: mean infection intensity; a: amplitude of variation intensity; rd: relative density. 


\section{DISCUSSION}

Results obtained in this research work indicate that in $P$. corruscans, proteocephalidean cestodes presented the greatest prevalence and mean intensity of infection, favoured by the alimentary habit of this species. This host has a great economic and ecological importance since it is the second most important predator of the basin. It is a migratory species with strictly carnivorous habits (Ringuelet et al. 1967). The existence of proteocephalidean adults indicate that this host is a superior level component in the alimentary chain, thus corroborating the results of analyzes of their stomachal contents obtained by Marques (1993) and by UEM/ NUPELIA (unpublished observations), classifying the species as essentially piscivorous. According to Marques (1993) and Agostinho et al. (1995) the host's alimentary spectrum contains approximately 30 species of fish. Fish act as a secondary intermediate host in the biological cycle of proteocephalideans (Pavanelli \& Machado dos Santos 1991, Eiras 1994), thus justifying the great predominance of these parasites in the host.

The diet of $S$. borelli is basically composed of Pomaceae, vegetal detritus and secondarily of algae and invertebrates which may possibly be associated to roots and other vegetative parts of the gramineae, and thus constituting part of the periphyton. This alimentary spectrum characterizes the species as pasturing herbivorous (Andrian et al. 1994). It presents an important role in the transference of allochthone energy to the aquatic environment since it takes food from the river bank (Dudgeon 1983), besides being of relative economical importance in the region.

Differences found between prevalence and mean intensity of parasites of $P$. corruscans and $S$. borelli are in accordance to Thoney (1991) who observed that these variations in different host species may be explained by their alimentary habits. According to Kennedy et al. (1986) a greater diversity of prey items contributes significantly to an increase in the number of specimens of parasites, justifying the results obtained in the present research work with regard to $P$. corruscans. The finding of indirect life cycle (adult) endoparasites in $S$. borelli may possibly be explained through the presence of intermediate hosts in the fauna associated to aquatic macrophytes taken by this host.

Since the populational fluctuation of intermediate hosts can influence the occurrence of heteroxenous parasites (Thoney 1991) the high prevalence of infection, especially in $P$. corruscans, suggests the availability of its intermediate hosts as preys and thus important determinants of infection.

A study of the histopathology of $P$. corruscans parasitized by larvae of Eustrongylides sp. in the
Cuiabá River, State of Mato Grosso, Brazil, revealed that the deterioration of parasites occurs in the older capsule (Eiras \& Rego 1988). However, one cannot discard the hypothesis that these hosts, especially the small ones, can be ingested by piscivorous birds and thus completing the cycle of these endoparasites. This fact together with the low infection prevalence of larval forms of nematodes in $P$. corruscans and of digenetic species in $S$. borelli suggests that these fish may have a function of being paratenic hosts of the parasites.

Since these two species of hosts have different habits and behaviour, belonging to different orders, it was expected that they would present differences in composition and prevalence of their endoparasitic fauna. This was proved in this study. Comparing the structure of the endoparasitic communities of the two species of hosts one may observe that they do not share the same parasite species even though both are sympatric.

Although $S$. borelli presented a greater number of endohelminth species (11) than that found in $P$. corruscans $(10)$, the diversity obtained by Shannon index was greater in the case of the latter. The greater number of species found in $S$. borelli may probably be due to the great number of invertebrate species from fauna associated to aquatic macrophytes taken by this host. Diversity is made up of two components inherent to parasitic infrapopulations: the parasitic richness (total number of species present in an infracommunity) and the uniformity (how abundance data are distributed among the species) (Ludwig \& Reynolds 1988), which may explain the greater endoparasitic diversity in $P$. corruscans.

Price and Clancy (1983), Bell and Burt (1991) and Guégan et al. (1992) postulated (a) that the diversity of endohelminths varies between sites or between species of hosts and (b) that the diversity of helminths is related to the size of the host, longevity and diet. They also claim that size and diet together explain approximately $40 \%$ of the variance in the diversity of endohelminths among different species of hosts. However, the absence of relationship between diversity and the host's length has already been shown with regard to the branchial parasites of freshwater fish (Adams 1986, Janovy \& Hardin 1988). Thus the absence of relationship between endoparasitic diversity and the body length of the two host species under analysis may indicate that their diet does not vary according to their growth. This fact indicates homogeneity in their behaviour during all their life and thus permits the uniform recruitment of the same species of endoparasites throughout their ontogenetic evolution. It may be suggested that the difference in the feeding habit existing between these two host species is one of the most relevant factors for ex- 
plaining the difference of endoparasitic diversity in both species and the great endoparasitic richness in P. corruscans. Thus the species that occupy higher trophic levels present favourable conditions to endoparasitic infections because they include a greater number of prey species in their diet.

The independence of diversity values with regard to sex of $P$. corruscans and $S$. borelli evidences that both fish ecological relationships (occupation of habitat and diet) are similar among males and females. Same results have been obtained for other species of freshwater fish (Adams 1986, Janovy \& Hardin 1988) and marine fish (Luque et al. unpublished observations).

In $P$. corruscans, Evenness index obtained was high and was probably related to the low value of Simpson index, indicating that no species of endoparasites presented such a high infection intensity that could influence the size of the other endoparasitic infrapopulations. A similar fact was found by Neraasen and Holmes (1975) who studied the distribution of cestodes in three species of geese. In S. borelli, the Evenness index was high too. However, Simpson index $(C=0.29)$ indicated the presence of one species, $C$. pinnai, whose infection intensity could be influencing the size of the other infrapopulations.

According to Bush's Importance index, the classification of endoparasitic infrapopulations is useful in the quantitative evaluation of their relative importance in the community of endoparasites in a given host. A great number of endoparasitic species of $P$. corruscans integrates the categories of dominant and codominant species, or rather, significantly contributes towards the endoparasitic community of its host.

In the case of both hosts, all the species of endoparasites analyzed presented a spatial aggregate pattern in agreement to the typical patterns of endoparasitism showed by some authors (Skorping 1981, Janovy \& Hardin 1987, Oliva et al. 1990). According to Anderson and Gordon (1982) this pattern of aggregate dispersion may have originated (1) from the heterogeneity of the host's behaviour; (2) by patterns of spatial aggregation in the distribution of infectant stages and (3) by the differences of susceptability and capacity of the hosts' immunological reaction. The first hypothesis may be disposed of in our study since both hosts presented homogeneity in their behaviour, as verified by the diversity results. Thus, it is possible that the spatial aggregate pattern of endoparasitic infracommunities of $P$. corruscans and $S$. borelli may be explained by the second and third hypotheses combined.

From the results obtained it may be observed that there is no evidence of competition among the species of endoparasites in the two host species since no negative association occurred. In $P$. corruscans, three species of endoparasites presented a high associative degree (C. abscissus- $S$. spinulifera; C. abscissus - N. sudobim and S. spinulifera - N. sudobim), suggesting that they have the same intermediate host. The lack of association among the endoparasites of $S$. borelli suggests that its intermediate hosts were not simultaneously ingested by the fish and thus the latter constitute different items in its diet. However, it is necessary that some factors related to the origins of associations should be taken into consideration, such as (a) low immunological resistance of hosts with regard to endoparasites; (b) different susceptabilities of hosts, (c) similarity or difference of intermediate hosts and (d) necessary conditions for the survival of parasites (Stone \& Pence 1978, Bush \& Holmes 1986).

Parasitic communities may be classified as (1) isolationists and unstable and (2) interactive and stable (Bush \& Holmes 1986, Holmes \& Price 1986, Stock \& Holmes 1988). Endoparasitic communities of both hosts were classified as isolationists and unstable since (1) there is an absence of central species, (2) there are unoccupied niches and (3) the species of endoparasites presented a low degree or absence of association. This agrees with Kennedy et al. (1986) who postulated that isolationist communities in fish are more frequent because (1) ectothermic species need less food, (2) they have reduced vagility, (3) they have a broad trophic spectrum and (4) they have high opportunistic feeding.

\section{ACKNOWLEDGEMENTS}

This paper is part of an interdisciplinary projet called "Environmental studies of the Paraná River floodplain in the area comprehending the mouth of the River Paranapanema and the Itaipu Reservoir" undertaken with the help of PADCT/CIAMB-UEM. To NUPELIA (Nucleus for the Research in Limnology, Ichthyology and Aquiculture) for the logistic support.

\section{REFERENCES}

Adams AM 1986. The parasite community on the gills of Fundulus kansae (Garman) from the South Platte River, Nebraska (USA). Acta Parasitol Pol 31: 47-54.

Agostinho AA, Vazzoler AEAM, Marques EE, Hahn NS 1995. Aspectos da biologia do pintado Pseudoplatystoma corruscans (Agassiz, 1829) no rio Paraná. In CAB Reunião Anual do Grupo de Avaliação Técnica de Siluriformes do Brasil, 1, 1990, Pirassununga. Anais... Pirassununga: CEPTA/ IBAMA - CIID/CANADÁ, (in press).

Amato JFR, Boeger WA, Amato SB 1991. Protocolos para laboratório - coleta e processamento de parasitos do pescado. Imprensa Universitária, Universidade Federal Rural do Rio de Janeiro, Itaguai, Rio de Janeiro, 81 pp. 
Anderson RM, Gordon DM 1982. Processes influencing the distribution of parasite numbers within host populations with special emphasis on parasite-induced host mortalities. Parasitology 85: 373-398.

Andrian IF, Torrente G, Ferretti CML 1994. Atividade alimentar das piavas Schizodon borelli Boulenger, 1900 e Schizodon altoparanae Garavello e Britski, 1990 (Characiformes, Anostomidae), na planície de inundação do alto rio Paraná $\left(22^{\circ} 40^{\prime}-22^{\circ} 50^{\prime} \mathrm{S} /\right.$ $53^{\circ} 15^{\prime}-53^{\circ} 40^{\prime} \mathrm{W}$ ), Brasil. Rev UNIMAR 16 (supl.): 107-116.

Bell G, Burt A 1991. The comparative biology of parasite species diversity: internal helminths of freshwater fish. J Anim Ecol 60: 1047-1063.

Bush AO, Holmes JC 1986. Intestinal helminths of lesser scaup ducks: An interactive community. Can J Zool 64: 142-152.

Dogiel VA 1970. Ecology of the parasites of freshwater fishes, p. 1-47. In VA Dogiel, GK Petrushevski, YI Polyanski (eds), Parasitology of Fishes. T. F. H. Publications, Inc. Ltd,The British Crown Colony of Hong Kong, Hong Kong.

Dudgeon D 1983. The utilization of terrestrial plants as a food source by the fish stock of a gently sloping marginal zone in Plover Cove reservoir, Hong Kong. Environ Biol Fishes 8: 73-77.

Eiras JC 1994. Elementos de Ictioparasitologia. Fundação Eng. António de Almeida: Porto, 339 pp.

Eiras JC, Rego AA 1988. Histopatologia em peixes do rio Cuiabá (Mato Grosso) por larvas de Eustrongylides sp. (Nematoda, Dioctophymidae). Rev Bras Biol 48: 273-280.

Fowler HW 1951. Os peixes de água doce do Brasil. Arquivos de Zoologia de São Paulo 6: 405-625.

Guégan J-F, Lambert A, Lévêque C, Combes C, Euzet L 1992. Can host body size explain the parasite species richness in tropical freshwater fishes? Oecologia 90: 197-204.

Holmes JC, Price PW 1986. Communities of parasites, Cap. 9. In J Kikkawa, DI Anderson (eds), Cотmunity Ecology: Pattern and Process. Blackwell Scientific Publications, Oxford.

Janovy J, Hardin EL 1987. Populations dynamics of the parasites in Fundulus zebrinus in the Platte river of Nebraska. J Parasitol 73: 689-696.

Janovy J, Hardin EL 1988. Diversity of the parasite assemblage of Fundulus zebrinus in the Platte River of Nebraska. J Parasitol 74: 207-213.

Janson S, Vegelius J 1981. Measures of ecological association. Oecologia 49: 371-376.

Kennedy CR, Bush AO, Aho JM 1986. Patterns in helminth communities: why are birds and fish different? Parasitology 93: 205-215.

Ludwig JA, Reynolds JF 1988. Statistical Ecology: A Primer on Methods and Computing. WileyInterscience Publications, New York, 337 pp.

Machado MH, Pavanelli GC, Takemoto RM 1994. Influence of host's sex and size on endoparasitic infrapopulations of Pseudoplatystoma corruscans and Schizodon borelli (Osteichthyes) of the high Paraná River, Brazil. Rev Bras Parasitol Vet 3: 143-148.

Machado MH, Pavanelli GC, Takemoto RM 1995. Influence of the type of environment and of the hy- drological level variation in endoparasitic infrapopulations of Pseudoplatystoma corruscans (Agassiz, 1829) and Schizodon borelli (Boulenger, 1900) (Osteichthyes) of the upper Paraná River, Brazil. Rev Brasil Zool, in press.

Margolis L, Esch GW, Holmes JC, Kuris AM, Schad GA 1982. The use of ecological terms in parasitology (report of an Ad hoc Committee of the American Society of Parasitologists). J Parasitol 68: 131-133.

Marques EE 1993. Biologia reprodutiva, alimentação natural e dinâmica da nutrição de pintado, Pseudoplatystoma corruscans (Agassiz, 1829) (Osteichthyes, Pimelodidae) no alto rio Paraná. M. Sc. thesis. Universidade Federal do Paraná, Curitiba, Paraná, 104 pp.

Neraasen TG, Holmes JC 1975. The circulation of cestodes among three species of geese nesting on the Anderson River Delta. Acta Parasitol Pol 23: $277-$ 289.

Oliva M, Luque JL, Iannacone JA 1990. The metazoan parasites of Stellifer minor (Tschudi, 1844): An ecological approach. Mem Inst Oswaldo Cruz 85: 271274.

Pavanelli GC, Machado dos Santos MH 1991. Proteocefalídeos parasitos de peixes, em especial pimelodídeos, do rio Paraná, Paraná. Rev UNIMAR 13: $163-175$.

Pielou EC 1976. Mathematical Ecology. 2nd ed. WileyInterscience Publishers, New York, 385 pp.

Price PW, Clancy KM 1983. Patterns in a number of helminth parasites species in freshwater fishes. $J$ Parasitol 69: 449-454.

Ringuelet RA, Aramburu RA, Aramburu AA 1967. Los Peces Argentinos de Agua Dulce. Comissión de Investigación Científica, La Plata, 602 pp.

Skorping A 1981. Seasonal dynamics in abundance, development and pattern of infection of Bunodera luciopercae (Müller) in perch, Perca fluviatilis L. from an oligotrophic lake in Norway. J Fish Biol 18: 401-410.

Stock TM, Holmes JC 1988. Functional relationships and microhabitat distributions of enteric helminths of grebes (Podicipedidae): the evidence for interactive communities. J Parasitol 74: 214-227.

Stone JE, Pence DB 1978. Ecology of helminth parasitism in the bobcat from West Texas. $J$ Parasitol 64: 295-302.

Thomaz SM 1991. Influência do regime hidrológico (pulsos) sobre algumas variáveis limnológicas de diferentes ambientes aquáticos da planície de inundação do alto rio Paraná, MS, Brasil. M. Sc. thesis. Universidade Federal de São Carlos, São Carlos, São Paulo, 294 pp.

Thoney DA 1991. Population dynamics and community analysis of the parasite fauna of juvenile spot, Leiostomus xanthurus (Lacépède) and Atlantic croaker, Micropogonia undulatus (Linnaeus), (Sciaenidae) in two estuaries along the middle Atlantic coast of the United States. J Fish Biol 39: 515-534.

Thul JE, Forrester DJ, Abercrombie CL 1985. Ecology of parasitic helminths of wood ducks Aix sponsa, in the Atlantic Flyway. Proc Helminthol Soc Wash 52: 297-310. 